\title{
The Dominant Weed Type In Three Areas Of Mature Palm Oil On Peatland
}

\author{
Lili Dahliani*, Suryati Nadila Elban \\ \{leogirlteteh@gmail.com, elbannadila@gmail.com\} \\ Institut Pertanian Bogor
}

\begin{abstract}
Some Dominance Ratio (SDR) is the quadrant method that is one of the vegetation analysis used to find out the weeds that dominate the oil palm planting area which is the determinant in the implementation of control. The research objectives were to find out of the types of weeds that had grown dominantly in the oil palm plantation at collecting point area, the pathway, and on the circle area on peat soil based on SDR values and compare those values. The method in this study is the quadrant method for analysis of weed vegetation and t test. The research was carried out in the oil palm and mineral soil areas of PT Sampoerna Agro in North Sumatra. The results showed that the types of weeds that had grown dominantly in the oil palm plantation on block $16 \mathrm{C}$ were Kentosan, Axonophus compressus, Cyrtococcum accrescens, and Borreria alata. Kentosan and Axonopus compressus had grown dominantly in collecting point area with SDR values of 30\%, and 70\%. Borrearia latifolia and Borreria alata had grown dominantly in the circle area with SDR value of $24 \%$. Axonopus compressus and Cyrtococcum accrescens had grown dominantly in the path area with SDR value of $29 \%$. The results of the $t$ test carried out on the SDR of all types of weeds on the circle, on the path and in collecting point showed significantly different results.
\end{abstract}

Keywords: quadrant, circle, path, collecting point, and vegetation

\section{Introduction}

\subsection{Background}

Palm oil (Elaeis quineensis Jacq.) is very important for Indonesia, as a primary export commodity which are expected to increase the Indonesia planters income. The area of palm oil in Indonesia has increased significantly from year to year, in 2016 its area reached 11672861 ha (acre), supplying production by $54 \%$ of the world's needs 64.9 million tons with export volume worth 17. 8 billion USD [1]. Palm Oil commodities are very susceptible to weed competition because they negatively affect to plant growth and production which decrease in crop productivity [2].

Weed is a pests plant that grows around the area of oil palm, causing loss, is a competitor of staple crops in getting sunlight, $\mathrm{CO} 2$, and growing space [3]. In addition to reducing the ability of palm oil production, weeds can also pollute the quality of production, disrupt the smooth maintenance work, cause disruption to human health, increase agricultural business costs, reduce the efficiency of irrigation systems caused by water weeds, interfere with the penetration of sunlight to the surface of the water, at risk against toxic chemicals released by certain types of weeds (allelopathy), also results in water wastage due to faster evaporation and weeds inhibiting water flow [4].

Losses due to weeds for plantation crops vary greatly depending on the type of crop, climate, type of weed, and conditions in the field. Areas dominated by dangerous weeds or 
heavy competitors such as vines (Mikania micrantha), reeds (Imperata cylindrica), and Asystasia cromandeliana can reduce production by up to $20 \%$ [5]. The classification of palm oil weeds based on the life cycle consists of annual weeds, two years (Biennal Weeds), and annual weeds (Parennial Weeds). Based on its response to herbicides, weeds are grouped into grass weeds, puzzles and broadleaf weeds [4].

One of the growth and development of weeds is determined by the environmental conditions of the oil palm plantation area. One of the environmental conditions is the type of soil. Peat soil is soil that is formed from the remains of animals or plants both in the wilted or not withered condition that has undergone an imperfect decomposition process. [6] the characteristics of peat soils are very different from peat soils the difference lies in the chemical, physical, and biological properties of the soil. Therefore, the use of peat for agriculture in general is more "problematic" than peat soils, which requires more inputs and more complex management models. [7] there are several types of weeds in peatlands, namely fern weeds, weeds, and broad-leaf weeds.

Some Dominance Ratio (SDR) is a quadrant method, which is one of the vegetation analyzes used to find out the weeds that dominate oil palm planting areas. Weeds that dominate have a high ability in the mastery of growth facilities and living space, so they will be decisive in implementing control, whether weeds are important or not. SDR can describe the relationship of the amount of dominance between one type of weed with other types of weeds in a certain area, the greater the value of SDR weeds, the more dominant weeds. SDR is one of the considerations in controlling weeds in the area of oil palm cultivation so that the control is efficient and effective both on economic and ecological aspects.

\subsection{Objective}

The objectives of this study are:

1. Knowing the types of weeds that grow in the area of oil palm plantations, both at the collecting point, pathway or on a circle on peatland.

2. Determine the type of weed that dominates the area of oil palm plantations in the three locations on peat land based on SDR values.

3. Comparing SDR values according to the type of weeds that grow in the three oil palm planting locations on the peat land whether there is a real difference.

\section{Methodology}

\subsection{Place and Time}

This study / study was carried out in the peatland oil palm area on block 31D of PT Sampoerna Agro Tbk Hikmah One plantation, located in North Sumatra Province. April 28, 2018

The study / study was conducted for twelve weeks starting from February 5, 2018 to

\subsection{Tools and Materials}

The tools used are: Wood for stakes, rapia ropes, nylon threads, cameras, writing instruments, minitab programs, and oil palm plants in a 60-year-old block of 60 with the condition of the plant stems is very high and the condition of the midrib has covered the area underneath. 


\subsection{Implementation Methode}

1. Analysis of Weed Vegetation

Analysis of weed vegetation was carried out by the quadrant method, namely the sampling method with quadratic plots, square areas of various sizes $1 \mathrm{~m} \times 1 \mathrm{~m}$., As shown in the following figure. Analysis of weed vegetation was carried out on blocks 60 of oil palm plantations, in circle, path, and collecting point by making four (4) square plots. Each square plot was then identified the types of weeds that grow and determined the weed types by matching with the existing weed literature. The magnitude or variable measured by the quadrant method this time is the ratio of total dominance (SDR)

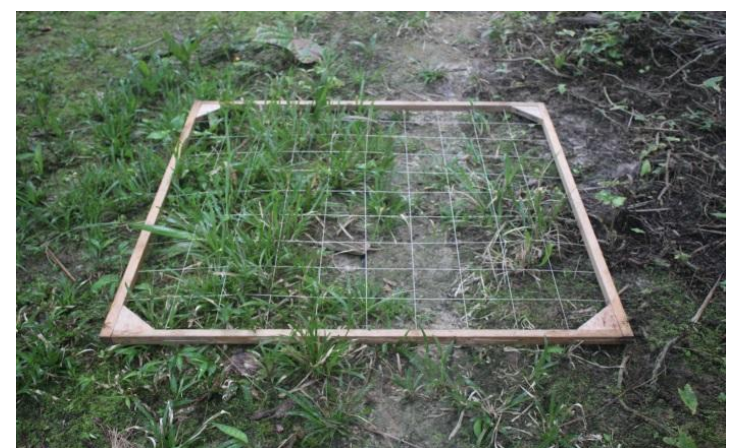

Fig. 1 Figure Analysis of Weed Vegetation Using Quadran

\subsection{T test}

Different test based on SDR is the dominant type of weed in the circle, path, and collecting point using $\mathrm{T}$ test. The real difference test was carried out between SDR of all types of weeds that grew on a circle with a path, between SDR on a circle with collecting poin and between SDR on a path with a circle. Different tests were also carried out between SDR of one type of weed that grew on a circle, path, or collecting point. This difference test is only carried out on the types of weeds that grow in these three areas (circle, path, and collecting point).

\section{Results And Discussion}

Different tests based on SDR are the dominant type of weed in the circle, path, and collecting point using $T$ test. The real difference test was carried out between SDR of all types of weeds that grew on a circle with a path, between SDR on a circle with collecting point and between SDR on a pioneer's path with a dish. Different tests were also carried out between SDRs of one type of weed that grew on a circle, paved road, or collecting point. This difference test is only carried out on the types of weeds that grow in these three areas (circles, path, and collecting point). Borreria alata and Onion weeds only grow in the circle area, Melastoma malabathricum, Centotheca lappacea, Nephrolepis exaltata, Chromolaena odorata and Eleusine indica only grow in the paved area. Borreria alata weeds can usually adapt to all environmental conditions. Can grow on coffee, tea, banana, cocoa, palm oil and rubber plantations. Can live in wetlands, along rivers. Usually abundant as a nuisance plant, the main 
grass in the garden, and an intermediary along the river, and in planting. Wild onion weeds can usually be found at an altitude of 200-200 meters above sea level, with a soil pH of 6-7. Fertile soil, crumbly soil structure and high organic matter content.

Borreria alata and Onion weeds only grow in the circle area, Melastoma malabathricum, Centotheca lappacea, Nephrolepis exaltata, Chromolaena odorata and Eleusine indica only grow in the paved area. Borreria alata weeds can usually adapt to all environmental conditions. It can grow on coffee, tea, banana, cocoa, palm oil and rubber plantations and can live in wetlands, along rivers, also. Usually abundant as a plant, the main grass in the garden, and an intermediary along the river, and in planting. Wild onion weeds can usually be found at an altitude of 200-200 meters above sea level, with a soil pH of 6-7. Fertile soil, crumbly soil structure and high organic matter content.

Weed Chromolaena odorata can grow well on all types of soil and will grow even better if you get enough sunlight. The ideal conditions for these weeds are areas with rainfall> $1,000 \mathrm{~mm} /$ year. Weed Clidemia hirta only grows in the area of oil palm collecting point because this weed habitat grows in areas that get enough direct sunlight such as in open areas, forest areas, sleeping forests, river banks and oil palm, rubber and tea plantations. Eleusine indica is a grassy weed that belongs to the Poaceae family. This weed can grow well in moist soil or not too dry and open or slightly shaded. It can grow well at an altitude of $0-1600 \mathrm{~m}$ above sea level. SDR values of weeds in the $16 \mathrm{C}$ block, paved road and collecting point of oil palm plantations are shown in the following table.

Table 1. Weed SDR on Blok $16 \mathrm{C}$ of Mature Palm Oil Plantation

\begin{tabular}{lrrr}
\hline \multicolumn{1}{c}{ Kind of weed } & \multicolumn{3}{c}{ SDR } \\
\cline { 2 - 4 } \multicolumn{1}{c}{ circle } & path & collecting point \\
\hline Kentosan & $21 \%$ & $9 \%$ & $30 \%$ \\
Axonopus compressus & $0 \%$ & $29 \%$ & $70 \%$ \\
Asystasis intrusa & $18 \%$ & $2 \%$ & $0 \%$ \\
Borreria latifolia & $24 \%$ & $5 \%$ & $0 \%$ \\
Stenochlaena palustris & $5 \%$ & $2 \%$ & $0 \%$ \\
Cyrtococcum accrescens & $0 \%$ & $29 \%$ & $0 \%$ \\
Borreria alata & $24 \%$ & $0 \%$ & $0 \%$ \\
Bawang-bawangan & $20 \%$ & $0 \%$ & $0 \%$ \\
Melastoma malabathricum & $0 \%$ & $7 \%$ & $0 \%$ \\
Centotheca lappacea & $0 \%$ & $6 \%$ & $0 \%$ \\
Nephrolepis exaltata & $0 \%$ & $4 \%$ & $0 \%$ \\
Chromolaena odorata & $0 \%$ & $3 \%$ & $0 \%$ \\
Eleusine indica & $0 \%$ & $3 \%$ & $0 \%$ \\
\hline Source: Aulia (2018) & & &
\end{tabular}


The type of weeds that grow dominantly in the $16 \mathrm{C}$ block oil palm planting area are Kentosan, Axonophus compressus, Cyrtococcum accrescens, and Borreria alata. Kentosan and Axonopus compressus grew dominant in collecting point with SDR values of $30 \%$ and $70 \%$, respectively. Borrearia latifolia and Borreria alata grow dominantly in the circle area with SDR value of $24 \%$ and Axonopus compressus and Cyrtococcum accrescens grew dominant in the paved road area with SDR value of $29 \%$. Based on the results of the test conducted, between SDR all types of weeds on the circle with the paved road, the types of weeds on the paved road with collecting point and the types of weeds on the circle with collecting point are all significantly different. T test results between Kentosan weeds in the 3 areas of oil palm plantations for plots, path and collecting point showed significant differences with $\mathrm{P}$-values greater than 0.05 , as well as for the t test.

\section{Conclusion And Suggestion}

\subsection{Conclusion}

The dominant weed that grows in the area of the circle, paved road, and collecting point for planting oil palm on peat soil in block 31D of the Hikmah One PT Sampoerna Agro Tbk plantation, located in North Sumatra Province with a palm oil age of 22 years in the disk area is a wide leaf type weed namely Borreria sp. with SDR of $24 \%$, on the pioneers are Axonopus compressus and Cyrtococcum accrescens with SDR 29\%, while the dominant weed in collecting point is Axonopus compressus with SDR 70\%.

Kentosan weed is a type of weed that grows in 3 areas of oil palm plantations both on path, collecting point, and disks on peat soils. Whereas the Borreria alata and Onion weeds only grow in the disk area and the Melastoma malabathricum weed, Centotheca lappacea, Nephrolepis exaltata, Chromolaena odorata and Eleusine indica only grow in the paved road area.

T-tests conducted on SDR types of weeds on the path, collecting point and circle showed significantly different results. T test results between weeds in 3 areas of circle palm oil plantations, path, and collecting point showed significant differences with P-values greater than 0.05 .

\subsection{Suggestion}

Weed SDR, especially for the types of weeds that dominate, should be the basis for controlling weeds, so that the control becomes effective and efficient. To ensure the use of SDR in the decision to carry out weed control in the field, further research is needed on this matter. 


\section{References}

[1] Direktorat Jenderal Perkebunan. 2017. Statistik Perkebunan Indonesia Komoditas Kelapa Sawit. [Internet]. [diunduh 2017 Sep 13]. Tersedia pada: http://ditjenbun.pertanian.go.id/

[2] Pahan I. Panduan Teknis Budidaya Kelapa Sawit. Jakarta (ID): Penebar Swadaya.

[3] Sembodo D. 2010. Gulma dan Pengelolaannya. Yogyakarta (ID): Graha Ilmu.

[4] Lubis R, Widanarko A. 2011. Buku Pintar Kelapa Sawit. Jakarta (ID): AgroMedia Pustaka.

[5] Sulistyo E, Purba A, Siahaan D, Efendi J, Sidik A. 2010. Budi Daya Kelapa Sawit. Jakarta (ID): Balai Pustaka. 